\title{
BEYOND REALISM
}

\author{
留 \\ Turgenev's Poetics \\ of Secular Salvation
}





\title{
BEYOND REALISM
}

\author{
Turgenev's Poetics \\ of Secular Salvation
}

Elizabeth Cheresh Allen

Stanford University Press Stanford, California I992 
Stanford University Press

Stanford, California

(C) 1992 by the Board of Trustees of the Leland Stanford Junior University

CIP data appear at the end of the book 
To JSA and RLJ 
